\title{
Influence of Bio-Coal Properties on Carbonization and Bio-Coke Reactivity
}

\author{
Asmaa A. El-Tawil 1,* , Bo Björkman ${ }^{1}$, Maria Lundgren ${ }^{2}$, Astrid Robles ${ }^{2}$ and Lena Sundqvist Ökvist ${ }^{1,2}$ \\ 1 MiMeR, Luleå University of Technology, 97187 Luleå, Sweden; Bo.Bjorkman@ltu.se (B.B.); \\ lena.sundqvist-oqvist@ltu.se (L.S.Ö.) \\ 2 Swerim AB, Box 812, 97125 Luleå, Sweden; Maria.Lundgren@swerim.se (M.L.); \\ Astrid.Robles@swerim.se (A.R.) \\ * Correspondence: asmaa.el-tawil@ltu.se; Tel.: +46-920-493131
}

Citation: El-Tawil, A.A.; Björkman, B.; Lundgren, M.; Robles, A.; Sundqvist Ökvist, L. Influence of Bio-Coal Properties on Carbonization and Bio-Coke Reactivity. Metals 2021, 11, 1752. https://doi.org/10.3390/ met11111752

Academic Editor: Pasquale Cavaliere

Received: 28 September 2021

Accepted: 26 October 2021

Published: 31 October 2021

Publisher's Note: MDPI stays neutral with regard to jurisdictional claims in published maps and institutional affiliations.

Copyright: (c) 2021 by the authors. Licensee MDPI, Basel, Switzerland. This article is an open access article distributed under the terms and conditions of the Creative Commons Attribution (CC BY) license (https:/ / creativecommons.org/licenses/by/ $4.0 /)$.

\begin{abstract}
Coke corresponds to 2/3-3/4 of the reducing agents in $\mathrm{BF}$, and by the partial replacement of coking coals with $5-10 \%$ of bio-coal, the fossil $\mathrm{CO}_{2}$ emissions from the BF can be lowered by $\sim 4-8 \%$. Coking coal blends with $5 \%$ and $10 \%$ additions of bio-coals (pre-treated biomass) of different origins and pre-treatment degrees were carbonized at laboratory scale and with a $5 \%$ bio-coal addition at technical scale, aiming to understand the impact on the bio-coal properties (ash amount and composition, volatile matter content) and the addition of bio-coke reactivity. A thermogravimetric analyzer (TGA) connected to a quadrupole mass spectroscope monitored the residual mass and offgases during carbonization. To explore the effect of bio-coal addition on plasticity, optical dilatometer tests were conducted for coking coal blends with $5 \%$ and $10 \%$ bio-coal addition. The plasticity was lowered with increasing bio-coal addition, but pyrolyzed biomass had a less negative effect on the plasticity compared to torrefied biomasses with a high content of oxygen. The temperature for starting the gasification of coke was in general lowered to a greater extent for bio-cokes produced from coking coal blends containing bio-coals with higher contents of catalyzing oxides. There was no significant difference in the properties of laboratory and technical scale produced coke, in terms of reactivity as measured by TGA. Bio-coke produced with $5 \%$ of high temperature torrefied pelletized biomass showed a similar coke strength as reference coke after reaction.
\end{abstract}

Keywords: bio-coals; carbonization; gasification; reactivity; dilatation; fluidity

\section{Introduction}

The iron-ore-based blast furnace (BF) process is still the most dominant method for producing metallic iron units for steelmaking [1]. In the BF, the high-quality metallurgical coke that is used is considered crucial for the process. Besides working as a reducing agent for iron ore, coke also serves as the structural support for the burden in the furnace and provides passages for the upward movement of reducing gases [1]. The total consumption of coke is about $300 \mathrm{~kg} / \mathrm{t}$ hot metal [1], depending on the amount of auxiliary reducing agents used (coke, coal, oil natural gas, etc.) [2]. The iron and steel industry aims to decrease the use of fossil carbon to minimize $\mathrm{CO}_{2}$ emissions. According to the World Steel Association, the iron and steel industry accounts for approximately $7-9 \%$ of total world $\mathrm{CO}_{2}$ emissions [3].

The use of pre-treated biomass (bio-coal) as a part of the raw material blend for cokemaking could be one possible way of reducing the fossil $\mathrm{CO}_{2}$ emissions linked to the $\mathrm{BF}$ process. The advantage of replacing part of the fossil coal with bio-coal is that the biomass regeneration time is comparatively short [4] and the effects on global warming can be reduced as the carbon cycle is closed [5]. It has been reported that with the partial replacement of coking coals with $5-10 \%$ of bio-coal, the fossil $\mathrm{CO}_{2}$ emissions at the $\mathrm{BF}$ can be lowered by $\sim 4-8 \%$ [6]. Using bio-coke (bio-coal-containing coke) in the BF has the potential to lower the thermal reserve zone temperature (TRZT) of the BF, as the gasification reaction 
(reaction of carbon in coke with $\mathrm{CO}_{2}$ ) can proceed at a lower temperature in the more reactive bio-coke. A lowering in the TRZT shifts the gas composition in the equilibrium of $\mathrm{FeO} / \mathrm{Fe}$ towards higher $\mathrm{CO}_{2}$ and lower $\mathrm{CO}$ contents. This leads to higher utilization of the input carbon for the reduction of the iron ore and lowers the required carbon input [7]. A higher reactivity will, however, also reduce the coke strength after reaction, which is not desirable, as it may cause disintegration and have an impact on the permeability.

During cokemaking the coking coals go through chemical and physical changes including softening, swelling, shrinking, evolution of volatile matter (VM), and, finally, re-solidification to obtain coke [8]. The thermoplastic properties of the coals are important for the quality of the final coke [9]. In bio-coke research, several types of biomass-based materials have been studied for evaluation of their effect on coal fluidity. This material includes different raw biomasses, torrefied biomass, and pyrolyzed biomass. The addition of any type of biomass decreases the fluidity of the coal blend [10-14]. Ueki et al. [12] reported that the addition of raw woody biomass during carbonization results in the formation of voids between coal particles during carbonization, due to the release of biomass $\mathrm{VM}$, and this results in brittle bio-coke. The coal particles were seen to be connected to woody biomass when they had a lower volatile content [12]. Diez et al. [11] reported that the thermal decomposition of raw biomasses (sawdust) occurs at low temperature $\sim 150-400{ }^{\circ} \mathrm{C}$ and the majority of VM are released before the plastic stage of coking coal occurs at around $400-500{ }^{\circ} \mathrm{C}$; this means that there is a lower amount of VM and remaining biomass that will interact with the coal during the fluidity development. On the other hand, Guerrero et al. [10] found that the devolatilization stages of coal and charcoal overlap partially and charcoal emits VM during carbonization that can block the fluidity, by establishing cross-linked O-C bonds. Fraga et al. [13] and Solar et al. [14] found that the addition of charcoal to coking coal blend caused a reduction in thermoplastic properties, and more so with increasing amounts. During the coal plastic stage charcoal acts as an inert material, which does not soften and melt, and as an active material that binds the components from the plasticized coal [11]. It was stated that chemically active additives, such as tar, petroleum residues, and oils, may act as fluidity enhancers or inhibitors, depending on their ability to donate or accept transferable hydrogen, respectively [9]. Generally, the blend of coal is required to have a maximum Gieseler fluidity and maximum dilatation greater than $400 \mathrm{ddpm}$ and $55 \%$, respectively, to produce high-quality metallurgical coke $[15,16]$.

The quality of coke affects the performance of the BF; thus, it must be strictly controlled. Mechanical strength, coke reactivity index (CRI), and coke strength after reaction (CSR) are the most important parameters used to define coke quality, which are measured according to ISO standards 1889-4 and 556, respectively. It has been reported that there is a strong correlation between CRI and CSR. When the CRI is low, the CSR is maintained at a high level [17].

Ash components such as oxides of alkali and alkaline earth metal and iron are known to act as catalysts in the gasification reaction [18-20]. Nomura et al. [7,21] found that coke containing a high content of $\mathrm{Ca}$ in non-coking coal has a high reactivity and that $\mathrm{Fe}$ and $\mathrm{Ca}$ act as catalysts during gasification. Grigore et al. [20] reported that the coke reactivity increased with the increasing total amount of mineral phases containing Ca. Babich et al. [22] found that coke with a higher porosity has a higher reactivity, which was explain by the fact that microporosity also affects the reactivity, because it enables the access of $\mathrm{CO}_{2}$ molecules to the inner part of the coke.

The effect of bio-coal particle size on the quality of bio-coke, in terms of CRI and CSR values, is reported in the literature [23-27]. The addition of $0.3-5 \%$ [14], 2-5\% [23,24], $5 \%$ [25], 2-10\% [26], 8\% [27], and 5-25\% [28] charcoal or (4.5-9\%) lignite [29] to the coking coal blend was studied. It was found that the CRI of bio-coke is higher in comparison to reference coke, and vice versa for CSR. The increase in the CRI was more pronounced with fine charcoal, due to the presence of calcium oxide, which acts as a catalyst that promotes the reaction of carbon with $\mathrm{CO}_{2}$, being more dispersed in the coke pieces compared to when using coarse charcoal $[14,23,24,26]$. It was shown that bio-coke has a higher reactivity 
when charcoal with a size $<0.07 \mathrm{~mm}$ was added, compared to when coarse charcoal (2-9 mm) was used, with 5\% charcoal addition [23,24], and further increased with 8\% [27] and $10 \%$ charcoal additions [26]. The cold strength of bio-coke was strongly affected by the addition of coarse charcoal, while the coke strength was preserved when adding fine charcoal [23-27]. The main drawbacks related to bio-cokes are the lower mechanical strength and strength after reaction compared to cokes produced from coking coals only. The low mechanical strength of bio-coke contributes to difficulties during handling and charging, as well as higher dust formation in the upper part of the BF. A low strength after reaction may result in the generation of fines within the $\mathrm{BF}$, especially in the lower part.

The carbonization behavior of coking coal blends containing raw or pre-treated biomass was reported in [12,14,23,24,26,28,30-33]. Matsumura et al. [30] studied the carbonization of raw biomass with one type of coking coal. Montiano et al. [32,33] studied the carbonization of industrial coal blends, containing more than six different coals, with the addition of two types of raw woody biomass: chestnut sawdust and pine sawdust. Solar et al. [14] studied the carbonization of an industrial coking coal blend with the addition of $0.3-5 \%$ of one type of charcoal. Ueki et al. [12], Florenonti et al. [31], and Yustanti et al. [28] studied the carbonization of coking coals with bio-coals produced from woody raw biomass or agricultural waste pre-treated at different temperatures and, therefore, with different VM and ash contents. Others $[23,24,26]$ have studied the carbonization of charcoal with different types of coals. No studies were found in which the aim was to understand the effect on carbonization and coke reactivity from bio-coal with different origins (different ash composition and cell structure) and different pre-treatments (pyrolysis degree, compaction through pelletizing) when adding up to $10 \%$ of the bio-coal in a coking coal blend consisting of three typical coking coals in the ratio used at industrial coking plants for the production of high-quality coke. Such a study would give information about the relative impact of applying bio-coal additions at an industrial coking plant.

In this study the effect on carbonization from the addition of different types of pretreated biomass to coking coal blends consisting of three coking coals, as typically used in European industrial plants, was investigated. The bio-coals used were of different pyrolysis degrees and origin, therefore, their properties differed, e.g., in terms of structure, VM, and ash composition, and this may influence their individual effects during coking and the properties of the produced bio-coke. The aim was to understand the impact of different bio-coal types on the carbonization and quality of bio-coke, depending on their properties, i.e., cell structure and reactivity, at added amounts of $5 \%$ or $10 \%$.

\section{Materials and Methods}

\subsection{Materials}

Three different types of coking coals, i.e., with low, medium, and high content of VM, were used in the coking coal blend, with or without the addition of bio-coal. Four types of bio-coals were selected based on their differences in VM and ash contents due to different pre-treatment temperatures and the origin of materials. The proximate and ultimate analysis, as well as the ash composition, for the bio-coals and the coking coals was analyzed according to the standard methods of ALS Scandinavia AB [34] and Swedish steel producer SSAB Europe in Luleå [35], respectively.

Carbonaceous materials are shown in Table 1; namely, torrefied biomass (TSD and TFR) from BioEndev AB (Holmsund, Sweden) [36] and Sveaskog AB (Stockholm, Sweden) [37], respectively, high-temperature torrefied biomass (HTT) from BioEndev AB and pyrolyzed biomass (CC) from Vindelkol AB (Vindeln, Sweden) [38], and three types of coking coals provided by SSAB Europe in Luleå, Sweden. HTT was densified through pelletizing before torrefaction. 
Table 1. Selected carbonaceous materials with abbreviations and their approximate pre-treatment temperatures.

\begin{tabular}{cccc}
\hline Carbonaceous Materials & Biomass Type & Temperature $\left({ }^{\circ} \mathbf{C}\right)$ & Abbreviation \\
\hline Torrefied forest residue & $\begin{array}{c}\text { Wood chips of tops } \\
\text { and branches of } \\
\text { pine/spruce }\end{array}$ & 270 & TFR \\
$\begin{array}{c}\text { Pine/Spruce } \\
\text { High temperature } \\
\text { torrefied }\end{array}$ & $\begin{array}{c}\text { Pelletized saw dust of } \\
\text { pine/spruce } \\
\text { Mixture of pieces of } \\
\text { pine, birch, alder, } \\
\text { aspen }\end{array}$ & 290 & TSD \\
Charcoal & - & 500 & HTT \\
High Volatile coal & - & - & CC \\
Medium volatile coal & - & - & HV \\
Low volatile coal & & - & MV \\
\hline
\end{tabular}

The proximate and ultimate analyses are presented in Table 2. The pre-treatment temperature of biomass affects their properties, e.g., VM, oxygen, and fixed carbon $\left(\mathrm{C}_{\mathrm{fix}}\right)$. The bio-coals prepared at low temperature (TFR and TSD) had a high content of VM and a low content of $\mathrm{C}_{\text {fix }}$; the opposite was the case for biomass pre-treated at high temperature (HTT and CC). The ash compositions are stated in Table 3. TFR has higher contents of catalytic components in terms of $\mathrm{K}_{2} \mathrm{O}, \mathrm{CaO}, \mathrm{Fe}_{2} \mathrm{O}_{3}$, and $\mathrm{Na}_{2} \mathrm{O}$ in comparison to TSD. The content of the catalytic components $\mathrm{K}_{2} \mathrm{O}, \mathrm{Fe}_{2} \mathrm{O}_{3}$, and $\mathrm{Na}_{2} \mathrm{O}$ is higher in HTT than in CC.

Table 2. Proximate and ultimate analysis for carbonaceous materials (dry base).

\begin{tabular}{ccccccccc}
\hline \multirow{2}{*}{ Abbreviation } & \multicolumn{3}{l}{ Proximate Analysis (wt \%) } & \multicolumn{5}{c}{ Ultimate Analysis (wt\%) } \\
\cline { 2 - 8 } & ${ }^{*} \mathbf{C}_{\text {fix }}$ & VM & Ash & $\mathbf{C}_{\text {tot }}$ & H & N & S & O \\
\hline TFR & 25.1 & 72.7 & 2.20 & 58.0 & 5.30 & 0.48 & 0.029 & 34.0 \\
TSD & 26.1 & 73.5 & 0.40 & 57.5 & 5.50 & $<0.1$ & $<0.01$ & 36.5 \\
HTT & 69.5 & 29.2 & 1.30 & 79.0 & 4.00 & 0.11 & 0.008 & 15.5 \\
CC & 80.7 & 18.6 & 0.70 & 87.0 & 3.40 & 0.25 & $<0.004$ & 8.30 \\
HV & 61.5 & 32.3 & 6.10 & 81.3 & 5.15 & 1.57 & 0.85 & 4.96 \\
MV & 67.4 & 24.0 & 9.0 & 81.4 & 4.46 & 1.86 & 0.50 & 3.10 \\
LV & 70.0 & 19.4 & 10.6 & 79.7 & 4.27 & 1.79 & 0.63 & 3.16 \\
\hline
\end{tabular}

$\mathrm{C}_{\text {fix }}$ fixed carbon; $\mathrm{VM}$ volatile matter, $\mathrm{C}_{\text {tot }}$ total carbon; $\mathrm{H}$ hydrogen; $\mathrm{N}$ nitrogen; $\mathrm{S}$ sulfur; $\mathrm{O}$ oxygen ${ }^{*} \mathrm{C}_{\mathrm{fix}}=100 \%-(\%$ Ash $+\% \mathrm{VM})$.

Table 3. Oxide content in the carbonaceous materials ( $\mathrm{w} t \%$, dry basis).

\begin{tabular}{ccccccccc}
\hline Abbreviation & $\mathrm{Al}_{\mathbf{2}} \mathbf{O}_{\mathbf{3}}$ & $\mathbf{C a O}$ & $\mathbf{S i O}_{\mathbf{2}}$ & $\mathrm{Fe}_{\mathbf{2}} \mathbf{O}_{\mathbf{3}}$ & $\mathbf{K}_{\mathbf{2}} \mathbf{O}$ & $\mathbf{M g O}$ & $\mathbf{M n O}$ & $\mathbf{N a}_{\mathbf{2}} \mathbf{O}$ \\
\hline TFR & 0.006 & 0.71 & 0.062 & 0.009 & 0.23 & 0.10 & 0.0053 & 0.018 \\
TSD & 0.005 & 0.16 & 0.028 & 0.007 & 0.073 & 0.023 & 0.017 & - \\
$\mathrm{HTT}$ & 0.020 & 0.31 & 0.26 & 0.086 & 0.14 & 0.058 & 0.039 & 0.02 \\
$\mathrm{CC}$ & 0.006 & 0.32 & 0.028 & 0.009 & $<0.002$ & 0.11 & 0.044 & $<0.009$ \\
$\mathrm{HV}$ & 1.79 & 0.074 & 3.28 & 0.507 & 0.010 & 0.049 & - & 0.0015 \\
$\mathrm{MV}$ & 2.85 & 0.11 & 4.68 & 0.482 & 0.007 & 0.067 & - & 0.0033 \\
$\mathrm{LV}$ & 3.11 & 0.12 & 6.25 & 0.409 & 0.012 & 0.069 & - & 0.0070 \\
\hline
\end{tabular}

The true density of the bio-coals was measured in a Micrometric Accupyc 1340 pycnometer (Micromeritics Instrument Corporation, South San Francisco, CA, USA). The sample was placed in a cell with a volume of $\sim 37.67 \mathrm{~cm}^{3}$ and the pores were filled with helium gas. The prepared sample had a particle size of 1-2 $\mathrm{mm}$ and was dried before measurements. The true densities were 1.34, 1.41, 1.44, and $1.51 \mathrm{~g} / \mathrm{cm}^{3}$ for TFR, TSD, HTT, and $\mathrm{CC}$, respectively, and the trend was for increasing density with higher pre-treatment temperature. 
The received data for the three different types of high-quality coking coals generated from Gieseler and dilatometer tests showed a max. dilatation and max. fluidity of $278 \%$, 107\%, and 69\% and 30,000 ddpm, $1092 \mathrm{ddpm}$, and $182 \mathrm{ddpm}$, for HV, MH, and LV coals, respectively. The Gieseler softening and re-solidification temperature for these coking coals was within the temperature range of $\sim 386-500{ }^{\circ} \mathrm{C}$.

\subsection{Methodology}

2.2.1. Thermoplastic Properties of Coking Coals Evaluated Using an Optical Dilatometer

The heating of a basic coal blend, BB, with and without a $5 \%$ and $10 \%$ addition of bio-coals was performed in an optical dilatometer from Leitz (Ernst Leitz Gmbh, Wertzlar, Germany), with an automatic image analysis system from Hesse Instruments (Hesse, Osterode am Harz, Germany). To secure the correct temperature readings, measurements were also conducted on zinc metal wire, of purity $99.996 \%$, and a thin piece of a bismuth-tin alloy, with known melting points of $419.3^{\circ} \mathrm{C}$ and $137^{\circ} \mathrm{C}$, respectively. The measured melting points were $409{ }^{\circ} \mathrm{C}$ and $137^{\circ} \mathrm{C}$, respectively.

The change in sample height and area with temperature was recorded and evaluated for similar parameters, as described in the standard ISO 23873. The main difference in comparison to the standard method is the lack of an applied load on the sample and the significantly smaller sample size. Due to the sample size and inhomogeneity of coals and bio-coals, variations in measurements can be expected. The variation test was repeated three times for two different coking coal blends with bio-coal, the standard deviation and standard error for the max dilatation were 0.98 and 0.56 , respectively, for the first sample, and for the second sample 2.00 and 1.15, respectively. The samples in these tests were $3 \mathrm{~mm}$ in diameter and $3 \mathrm{~mm}$ in height, compared to $60 \mathrm{~mm}$ in length and $8 \mathrm{~mm}$ in diameter in the standard method. The raw materials were finely pulverized in a mortar and mixed with water to achieve smooth sample surfaces. The sample was heated at a heating rate of $3{ }^{\circ} \mathrm{C} / \mathrm{min}$ to a final temperature of $550{ }^{\circ} \mathrm{C}$. Based on the area measurement of the sample, the swelling index, SI (\%), was calculated according to Equation (1).

$$
\text { SI }(\%)=\frac{\text { Change in area }}{\text { Original area }} \times 100
$$

\subsubsection{Preparation of Coke}

The recipes with relative additions of coking coals and bio-coal in the coal blend given in percentage weight are presented in Table 4 . As seen, the ratios of bio-coals added were $5 \%$ or $10 \%$. The blends with different bio-coal types added and the reference blend are presented in Table 5. The carbonaceous materials used were sieved and added to the coal blend in the proportions $19-21 \mathrm{wt} \%$ of $+2.8 \mathrm{~mm}$ fraction, $30-34 \mathrm{wt} \%$ of a fraction $-0.5 \mathrm{~mm}$, and the rest of the material was in between, $+2.8-0.5 \mathrm{~mm}$. The coking coals and bio-coal were mixed carefully, and water was added to reach $\sim 7.5 \%$ moisture. The mix was transferred into a graphite crucible with an inner diameter of $70 \mathrm{~mm}$ and an inner height of $210 \mathrm{~mm}$, and the crucible was then placed in a Tamman furnace (Berlin, Germany), as shown in Figure 1. Two-thirds of the crucible were packed with moist carbonaceous materials to achieve a bulk density of $\sim 800 \mathrm{~kg} / \mathrm{m}^{3}$. Furthermore, to record the temperature of carbonaceous materials during the coking, a thermocouple (k-type) in a protection tube of alumina was placed in the middle of the sample bed. A thermocouple (s-type) was used between the graphite crucible and the graphite tube to monitor the heating of the Tamman furnace. 
Table 4. The mixing ratio of coal blend with bio-coal (wt\%).

\begin{tabular}{cllcc}
\hline \multirow{2}{*}{ Coal Blend } & \multicolumn{4}{c}{ Recipe (wt\%) } \\
\cline { 2 - 5 } & HV & MV & LV & Bio-Coal \\
\hline Basic coal blend (BB) & 28.0 & 32.0 & 40.0 & - \\
BB + 5\% bio-coal & 26.6 & 30.4 & 38.0 & 5.0 \\
BB + 10\% bio-coal & 25.2 & 28.8 & 36.0 & 10.0 \\
\hline
\end{tabular}

Table 5. Added bio-coals and abbreviations of coking coal blends for carbonization in the Tamman furnace and the produced cokes.

\begin{tabular}{ccc}
\hline Bio-Coals & Coking Coal Blend & Coke \\
\hline- & HV, LV and MV & BB \\
TFR & BB $+5 \%$ TFR & TFR5 \\
& BB $+10 \%$ TFR & TFR10 \\
TSD & BB $+5 \%$ TSD & TSD5 \\
& BB $+10 \%$ TSD & TSD10 \\
HTT & BB $+5 \%$ HTT & HTT5 \\
& BB $+10 \%$ HTT & HTT10 \\
CC & BB $+5 \%$ CC & CC5 \\
& BB $+10 \%$ CC & CC10 \\
\hline
\end{tabular}

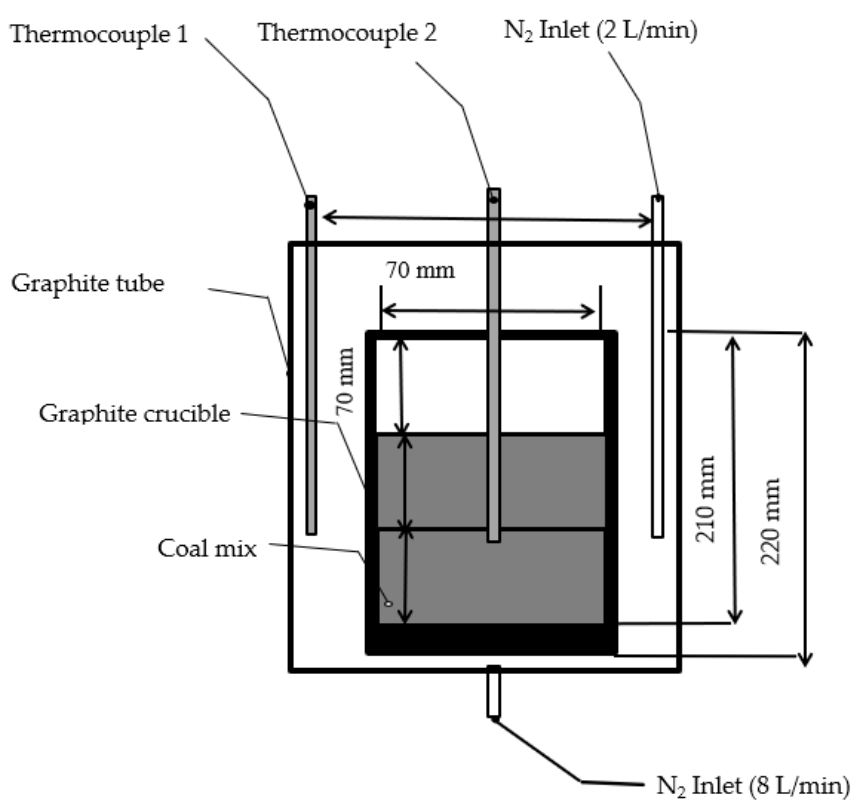

Figure 1. Schematic setup for cokemaking in the Tamman furnace.

The coal blends were heated under inert conditions using nitrogen gas (purity $99.996 \%$ and a flow rate of $10 \mathrm{~L} / \mathrm{min}$ ), according to the heating profile stated in Figure 2. The temperature increase was initially slow, and the samples were kept for $\sim 1.5 \mathrm{~h}$ at $100{ }^{\circ} \mathrm{C}$, then the sample was heated up to $1050{ }^{\circ} \mathrm{C}$, and the sample was maintained for $1.5 \mathrm{~h}$ at $1050{ }^{\circ} \mathrm{C}$, and finally the furnace was turned off and the coke was allowed to cool in $\mathrm{N}_{2}$ gas atmosphere. The produced coke was discharged from the crucible, crushed, and screened into a fraction of 1-2 $\mathrm{mm}$ and kept in a desiccator until characterization was carried out.

The coke yield was calculated according to Equation (2) and is presented in Table 8.

$$
\text { Coke yield }(\%)=\frac{\mathrm{m}_{1}}{\mathrm{~m}_{0}(1-\text { moisture } \% \times 0.01)}
$$


$\mathrm{m}_{1}$ is the remaining mass of coking coal blend after carbonization and $\mathrm{m}_{0}$ is the amount of coking coal blend before carbonization.

Selected coal blends, BB, TSD5, and HTT5, were also carbonized in a 10-kg-retort at DMT GmbH \& Co. KG in Essen, Germany [39]. The carbonaceous materials used were sieved to achieve the proportions $18-20 \mathrm{wt} \%$ of $+3.15 \mathrm{~mm}$ a fraction, and $30-34 \mathrm{wt} \%$ of a fraction $-0.5 \mathrm{~mm}$, and the rest was between 3.15 and $0.5 \mathrm{~mm}$. The small-scale coking test retort that was charged with approximately $\sim 11 \mathrm{~kg}$ of coking coal blend had a height of $50 \mathrm{~mm}$ and a diameter of $180 \mathrm{~mm}[40,41]$. The set points for moisture content and bulk density (wet) were $\sim 9 \%$ and $800 \mathrm{~kg} / \mathrm{m}^{3}$, respectively. The duration of carbonization at DMT was approximately $4 \mathrm{~h}$, and the final coke temperature was $\sim 1020^{\circ} \mathrm{C}$. The coke was analyzed for CRI, CSR (ISO 1889-4), and mechanical strength, using the Micum test, according to ISO556, but modified for smaller sample sizes according to [40]. CRI corresponds to the weight loss due to the carbon solution loss reaction of carbon in coke under a $\mathrm{CO}_{2}$ atmosphere at $1100{ }^{\circ} \mathrm{C}$ for $2 \mathrm{~h}$. Due to the gasification reaction consuming carbon, the outer layer of coke particles becomes porous and the mechanical strength against abrasion drops. To measure this effect, the reactivity test was followed by determination of CSR in a tumbler test, which corresponds to the percentage of particles that remain larger than $10 \mathrm{~mm}$ after 600 rotation [1]. The M40 and M10 deduced from the Micum test describe the resistance to physical degradation and were calculated from the percentage material remaining of +40 and $-10 \mathrm{~mm}$, respectively, after 100 revolutions. In Europe, the Micum (M40/M10) test for cold mechanical strength is commonly used and the acceptable ranges are $\mathrm{M} 40>80 \%$ and $\mathrm{M} 10<7 \%$ [17].

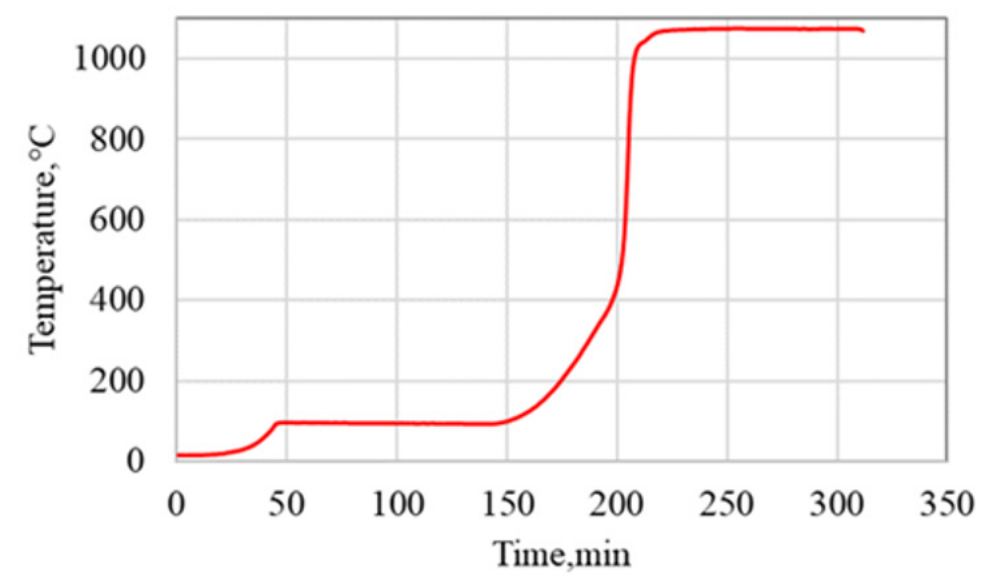

Figure 2. Typical temperature profile during carbonization in the Tamman furnace.

The textures of bio-coal, coke, and bio-cokes were investigated using a light optical microscope (LOM, Nikon ECLIPSE E600 POL, Tokyo, Japan). The samples were mounted in epoxy resin and the surfaces were polished before the studies. The chemical composition of coke prepared in the laboratory and technical scale was determined by SSAB Luleå using Thermo an ARL 9900 X-ray fluorescence (XRF) instrument (Zagreb, Croatia) with a rhodium tube at $50 \mathrm{kV}$ and $50 \mathrm{~mA}$.

\subsubsection{Thermogravimetric Analysis}

In this study two thermogravimetric analyzers were used. A TGA, Netzsch STA 409 instrument (sensitivity $\pm 1 \mu \mathrm{g}$, Columbus, OH, USA) attached to a Quadruple Mass Spectroscope (QMS, Netzsch, Selb, Germany) was used to monitor the mass loss and off-gas analysis, respectively, during the pyrolysis of carbonaceous materials. The TGA/QMS used in this study is described in detail in reference [42]. A TGA equipment Netzsch STA 409, with graphite furnace [8], was used when studying the reactivity of the coke and bio-coke.

Carbonization was done using TGA/QMS equipment. A sample of $150 \mathrm{mg}$ was placed in an alumina crucible and heated according to the heating profile presented in 
Figure 3. The carbonization was performed in an inert atmosphere of $\mathrm{N}_{2}$ gas (purity $99.996 \%$ ) having a flow rate of $200 \mathrm{~mL} / \mathrm{min}$.

Reactivity tests were performed using a $\mathrm{CO}_{2}$ atmosphere at a rate of $300 \mathrm{~mL} / \mathrm{min}$ for the coke and bio-coke samples that were carbonized in the Tamman furnace and at DMT. Particles of 1-2 mm size were used. Approximately 40-50 mg of the sample was placed in an alumina crucible with low edges, to avoid accumulation of formed $\mathrm{CO}$ in the sample and heated in TGA equipment and heated at $20^{\circ} \mathrm{C} / \mathrm{min}$ from room temperature up to $600^{\circ} \mathrm{C}$, and at $3^{\circ} \mathrm{C} / \mathrm{min}$ between 600 and $1100^{\circ} \mathrm{C}$.

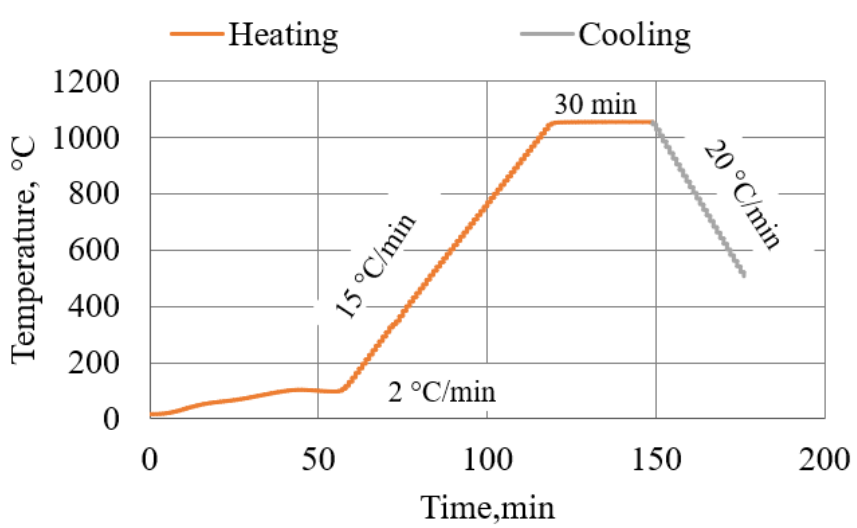

Figure 3. Heating profile used for the carbonization of carbonaceous materials in the TGA tests.

The accuracy of the balance and temperature for the graphite furnace was checked using calcium oxalate and gold in an argon atmosphere up to $1000{ }^{\circ} \mathrm{C}$ and $1100{ }^{\circ} \mathrm{C}$, respectively. The mass loss for calcium oxalate was $12.3 \%, 19.1 \%$, and $30.3 \%$ up to $300^{\circ} \mathrm{C}$, $600{ }^{\circ} \mathrm{C}$ and $1000{ }^{\circ} \mathrm{C}$, respectively, which can be compared with the reference data of $12.3 \%$, $18.9 \%$, and $30.2 \%$, with a tolerance of $\pm 0.2 \%$. The known melting point for gold is $1064{ }^{\circ} \mathrm{C}$, and the measured one was $1069^{\circ} \mathrm{C}$. The influence of the possible inhomogeneity in the coke sample was checked in a TGA, Netzsch STA 409 Spectroscope (QMS, Netzsch, Selb, Germany), and three reactivity tests was performed for one sample, while the TGA result showed consistent results without significant variations; the standard deviation for mass loss was $\pm 1 \%$.

\section{Results}

\subsection{Bio-Coals and Coal Properties}

\subsubsection{Structure of Bio-Coals}

Figure 4 shows LOM images of the four different types of bio-coals used in the coking coal blend. It is noted that the structure of the TFR is characterized by a spherical and compact structure, while samples of TSD showed a duct structure with elongated pores, as seen in Figure $4 \mathrm{a}$ and $4 \mathrm{~b}$, respectively. From the areas studied with the microscope, it was indicated that the TSD sample contained cells of larger size, $26-48 \mu \mathrm{m}$, compared to TFR, which had cells of sizes around 9-24 $\mu \mathrm{m}$. The structure of CC had a regular distribution of pores in a size between 40 and $79 \mu \mathrm{m}$, and it had a duct structure, as seen in Figure $4 \mathrm{~d}$. The texture of the HTT sample contained more collapsed pores, with a pore size between 6 and $11 \mu \mathrm{m}$, as seen in Figure 4c.

\subsubsection{Carbonization Behavior of Single Coals or Bio-Coals}

Table 6 shows the mass loss for carbonaceous materials at different temperatures. TSD and TFR had the most mass loss in the temperature range $200-400{ }^{\circ} \mathrm{C}$, while the $\mathrm{CC}$ and HTT had a main mass loss above $500^{\circ} \mathrm{C}$. It is seen that TSD had a higher mass loss than TFR at $200-400^{\circ} \mathrm{C}$. At temperatures above $400{ }^{\circ} \mathrm{C}$, TFR had a slightly higher mass loss than TSD. In general, the mass loss of bio-coals is higher than for coals. The maximum mass loss for coals occurs in the temperature range $400-500^{\circ} \mathrm{C}$. 


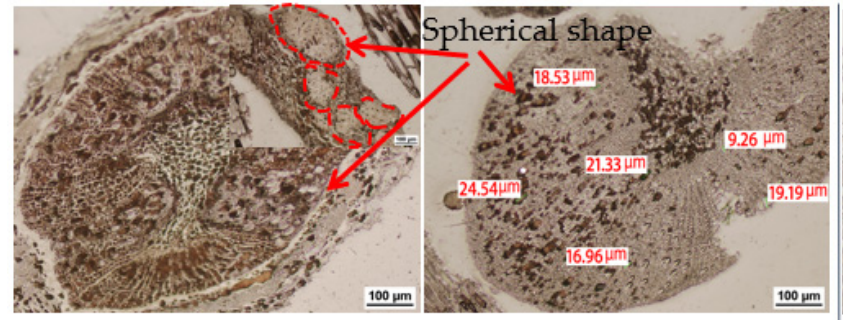

(a)

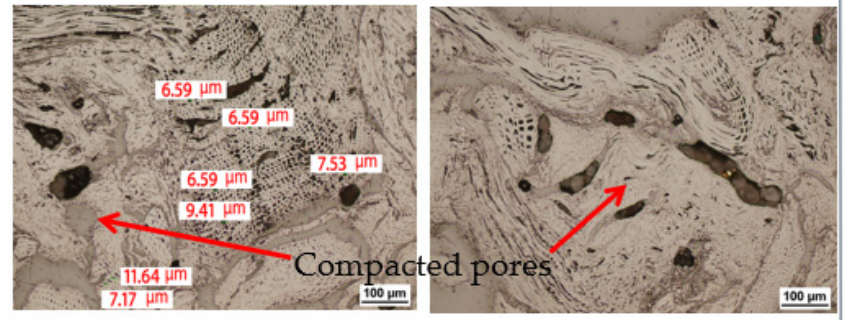

(c)

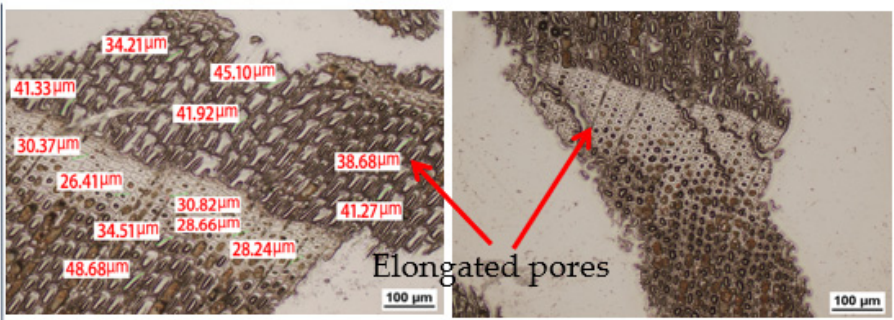

(b)
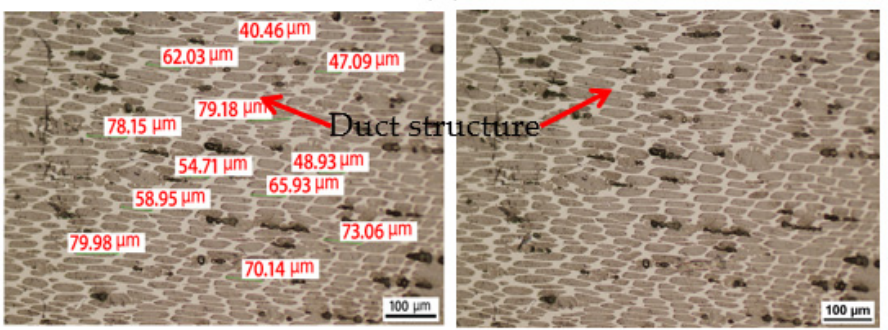

(d)

Figure 4. Microstructure images of bio-coals (a) TFR, (b) TSD, (c) HTT, and (d) CC.

Table 6. Mass loss (wt\%) for coals and bio-coals during carbonization.

\begin{tabular}{crrcc}
\hline Abbreviation & $\mathbf{2 0 0 -} \mathbf{4 0 0}{ }^{\circ} \mathbf{C}$ & $\mathbf{4 0 0 - 5 0 0}{ }^{\circ} \mathbf{C}$ & $\mathbf{5 0 0 - 8 0 0}{ }^{\circ} \mathbf{C}$ & $\mathbf{8 0 0 - 1 0 5 0}{ }^{\circ} \mathbf{C}$ \\
\hline TFR & 42.7 & 10.8 & 6.69 & 1.10 \\
TSD & 56.3 & 7.36 & 5.46 & 0.80 \\
HTT & 4.30 & 5.66 & 14.9 & 1.20 \\
CC & 3.63 & 3.93 & 13.3 & 1.22 \\
HV & 2.27 & 14.5 & 7.87 & 1.40 \\
MV & 1.79 & 11.1 & 8.83 & 1.17 \\
LV & 1.11 & 7.14 & 8.54 & 1.25 \\
\hline
\end{tabular}

During the thermal decomposition of bio-coals and coals the gases $\mathrm{H}_{2}, \mathrm{CO}, \mathrm{CO}_{2}, \mathrm{H}_{2} \mathrm{O}$, and ionized hydrocarbons such as $\mathrm{CH}_{4}^{+}, \mathrm{C}_{2} \mathrm{H}_{5}^{+}$were detected. However, the lengths of the carbon chains in the released hydrocarbons were probably initially longer, before thermal decomposition and excitation in the QMS. The highest ion currents recorded by QMS were for $\mathrm{m} / \mathrm{z}$ of $2,18,15,29$, and 44; judged to represent $\mathrm{H}_{2}, \mathrm{H}_{2} \mathrm{O}, \mathrm{CH}_{4}^{+}, \mathrm{C}_{2} \mathrm{H}_{5}^{+}$, and $\mathrm{CO}_{2}$, respectively. The recorded ion currents for $\mathrm{H}_{2}, \mathrm{H}_{2} \mathrm{O}, \mathrm{CO}_{2}$, and $\mathrm{CH}_{4}^{+}$are shown in Figure 5. Hydrocarbon such as $\mathrm{CH}_{4}^{+}$was detected at $290{ }^{\circ} \mathrm{C}$ for torrefied biomass (TFR and TSD) and at $455^{\circ} \mathrm{C}$ for pyrolyzed biomass (HTT and CC), see Figure 6a. Overlapping between the peaks for ionized hydrocarbons $\mathrm{CH}_{4}^{+}$was seen within the temperature range $430-630{ }^{\circ} \mathrm{C}$ for coals and all types of bio-coals. The release of $\mathrm{H}_{2}$ started at $310^{\circ} \mathrm{C}$ for TFR and TSD, while it started at $500{ }^{\circ} \mathrm{C}$ for pyrolyzed bio-coals and coals, see Figure $5 \mathrm{~b} . \mathrm{CO}_{2}$ was detected only for TFR and TSD within a temperature range of $119-770{ }^{\circ} \mathrm{C}$, with a slightly higher intensity peak at $350{ }^{\circ} \mathrm{C}$ for TSD, see Figure $5 \mathrm{c} . \mathrm{H}_{2} \mathrm{O}$ was detected from $115^{\circ} \mathrm{C}$ until $1050^{\circ} \mathrm{C}$ for all types of bio-coals, but TFR and TSD had a higher intensity peak at $340{ }^{\circ} \mathrm{C}$, see Figure $5 \mathrm{~d}$. 


$$
-\mathrm{TFR}-\mathrm{TSD}-\mathrm{HTT}-\mathrm{CC}-\mathrm{HV} \text {-coal }-\mathrm{MV} \text {-coal }- \text { LV-coal }- \text { Temperature, }{ }^{\circ} \mathrm{C}
$$
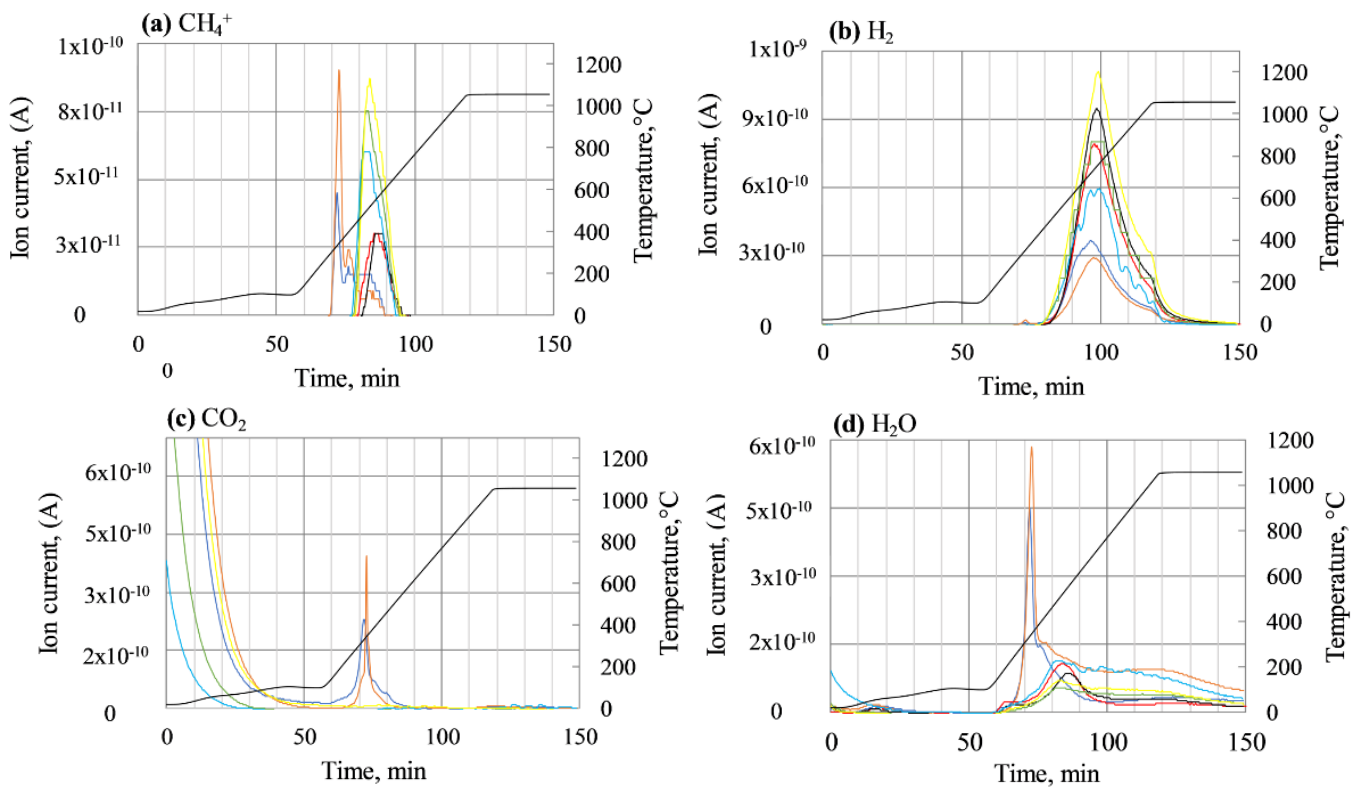

Figure 5. Off gas analysis of (a) $\mathrm{CH}_{4}^{+}$; (b) $\mathrm{H}_{2} ;$ (c) $\mathrm{CO}_{2}$; and (d) $\mathrm{H}_{2} \mathrm{O}$ for different types of bio-coals and coals at carbonization conditions in $\mathrm{N}_{2}$ atmosphere.

\subsection{Carbonization of Selected Coking Coal Blends in TGA}

The TGA results for the carbonization of $\mathrm{BB}$ and coal blend with a $10 \%$ addition of TFR and TSD are presented in Figure 6. The total mass loss achieved for TFR10 and TSD10 was higher than for BB. The devolatilization of TFR10 and TSD10 started at $\sim 290^{\circ} \mathrm{C}$ and $340{ }^{\circ} \mathrm{C}$, respectively, compared to at $\sim 40{ }^{\circ} \mathrm{C}$ for the BB. DTG analysis shows that the TFR10 and TSD10 had two devolatilization steps, while the main devolatilization for BB occurred in one step, above $400{ }^{\circ} \mathrm{C}$.

Hydrocarbon, such as $\mathrm{C}_{2} \mathrm{H}_{5}^{+}$, was detected at $300^{\circ} \mathrm{C}$ for TFR10 and TSD10, while it was detected at $400{ }^{\circ} \mathrm{C}$ for $\mathrm{BB}$, as seen in Figure $7 \mathrm{a}$. $\mathrm{CH}_{4}^{+}$was detected in the temperature range of $\sim 400-600{ }^{\circ} \mathrm{C}$, and the release of $\mathrm{H}_{2}$ started at $\sim 430{ }^{\circ} \mathrm{C}$ for all coking coal blends, see Figure $7 \mathrm{~b}$ and $7 \mathrm{c}$, respectively. The release of $\mathrm{CO}_{2}$ was negligible in all coking coal blends and is therefore not presented.

Plastic Properties of Coking Coal Blends

The results from the optical dilatometer tests for BB and blends with 5 or $10 \%$ addition of bio-coals are shown in Table 7. The results show that the max. dilatation of CC5 and HTT5 was quite similar to BB but dropped for the other coking coal blends. The drop in max. dilatation was more pronounced for coking coal blends containing $10 \%$ of biocoals, especially when using the torrefied bio-coals TSD and TFR. The swelling index, SI, decreased with the addition of bio-coals to the $\mathrm{BB}$, and the decrease was more significant for the addition of TFR, TSD, and HTT in comparison to CC. The coking coal blends produced from the mixtures BB, TSD5, and HTT5 were also analyzed at DMT using DIN 51739. The max. dilatation was found to be $48,-10$, and 41 for BB, TSD5, and HTT5, which was a similar trend as in the modified tests in the optical dilatometer. 


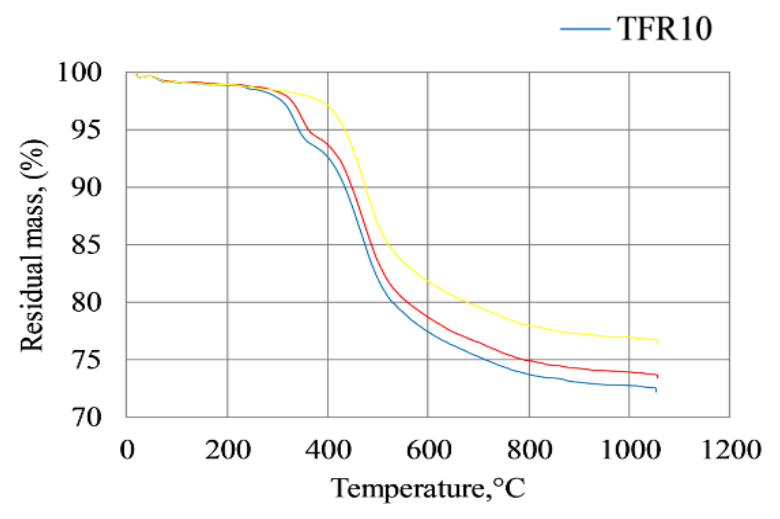

(a)

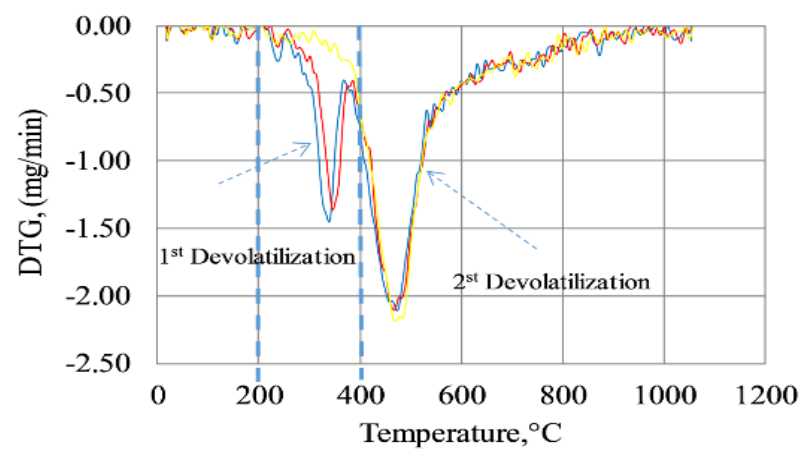

(b)

Figure 6. (a) TGA (b) DTG for TFR10, TSD10, and BB at carbonization conditions in $\mathrm{N}_{2}$ atmosphere.

\section{- TFR $10-$ TSD $10-$ BB - Temperature, ${ }^{\circ} \mathrm{C}$}
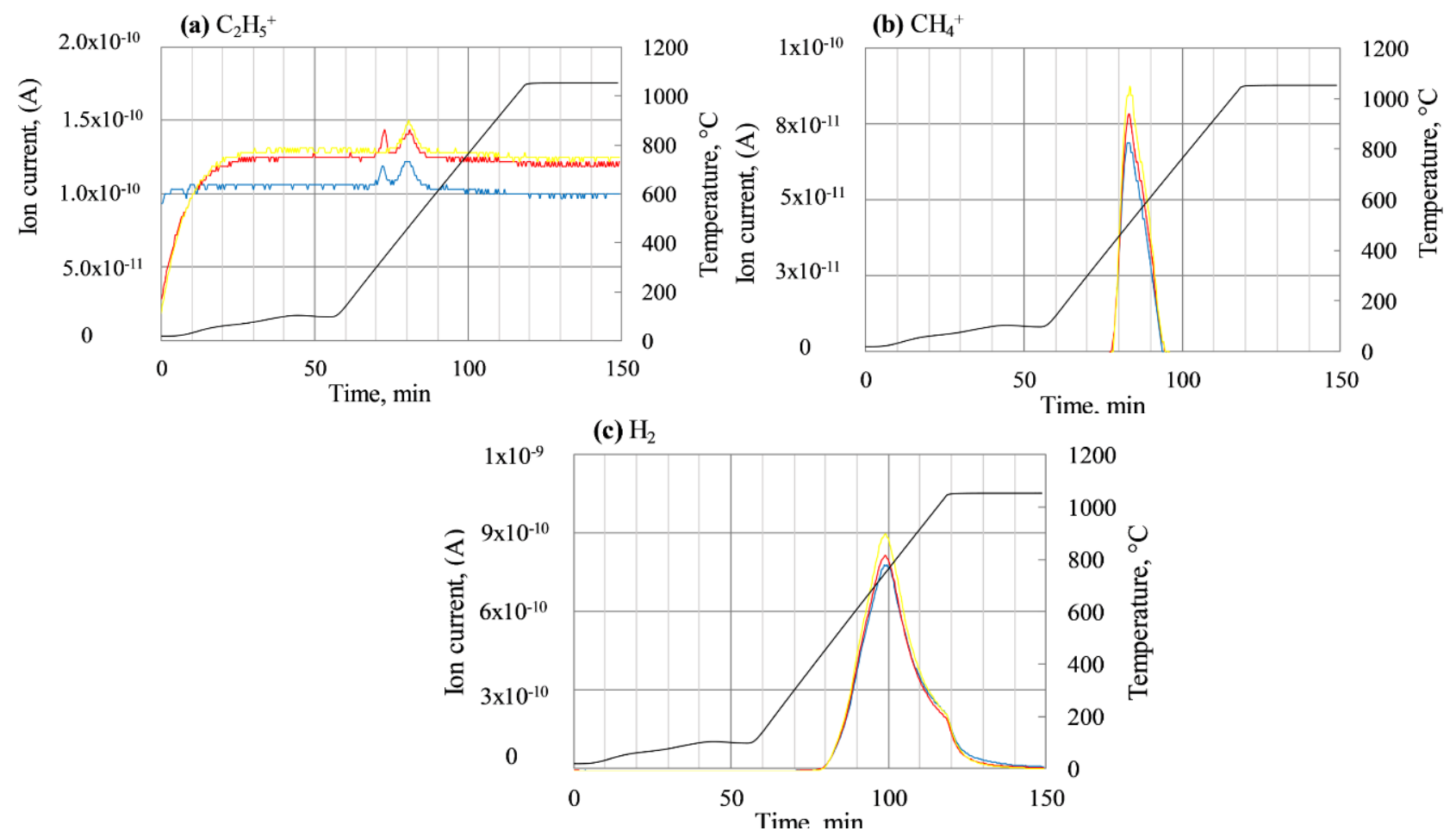

Figure 7. Off gases detected by QMS when testing coking coal blends at carbonization conditions in the TGA, $(\mathbf{a}) \mathrm{C}_{2} \mathrm{H}_{5}^{+}$, (b) $\mathrm{CH}_{4}^{+}$, and (c) $\mathrm{H}_{2}$; for TFR10, TSD10, and BB. 
Table 7. Thermoplastic parameters for the basic coal blend, BB, and coal blends with the addition of bio-coals, deduced from optical dilatometer tests.

\begin{tabular}{cccc}
\hline \multirow{2}{*}{ Coal Blend } & \multicolumn{2}{c}{ Max. Dilatation } & SI \\
\cline { 2 - 4 } & ${ }^{\circ} \mathbf{C}$ & $\mathbf{\%}$ & $\%$ \\
\hline BB & 436 & 15.8 & 68 \\
TFR5 & 425 & 10.4 & 22 \\
TSD5 & 430 & 8.29 & 19 \\
HTT5 & 423 & 15.2 & 20 \\
CC5 & 421 & 16.3 & 31 \\
TFR10 & 346 & -0.38 & - \\
TSD10 & 406 & -1.50 & 2 \\
HTT10 & 417 & 8.03 & 2 \\
CC 10 & 428 & 9.77 & 18 \\
\hline
\end{tabular}

SI: Swelling index.

\subsection{Properties of Coke}

\subsubsection{Laboratory Cokemaking}

Table 8 shows the coke yields for the produced coke and bio-coke. As could be expected, the coke yield was lower for bio-coke-containing torrefied bio-coals, TFR, and TSD, in comparison to bio-coke containing the pyrolyzed ones, HTT and CC.

Table 8. Coke yield (\%) of coke and bio-coke.

\begin{tabular}{ccccccccc}
\hline BB & TFR5 & TFR10 & TSD5 & TSD10 & HTT5 & HTT10 & CC5 & CC10 \\
\hline 76.5 & 70.4 & 74.0 & 75.1 & 73.6 & 78.5 & 77.0 & 77.7 & 76.5 \\
\hline
\end{tabular}

\subsubsection{Structure of Bio-Cokes and Chemical Composition}

The structure of the produced coke at laboratory and technical scales was examined in LOM. Figure 8 shows the TSD5 sample, which indicates that bio-coals possibly retained their structure after carbonization. The elongated duct cell shape seen for the TSD was also found in the coke, as seen in Figures $8 \mathrm{a}$ and $8 \mathrm{~b}$, respectively.

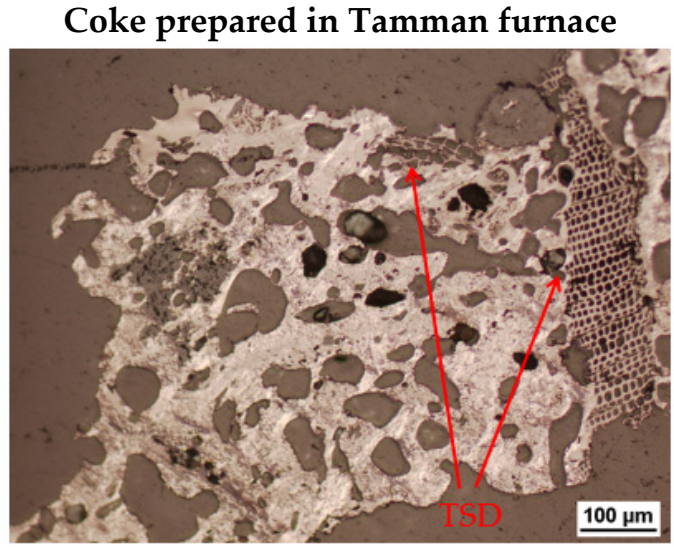

(a)

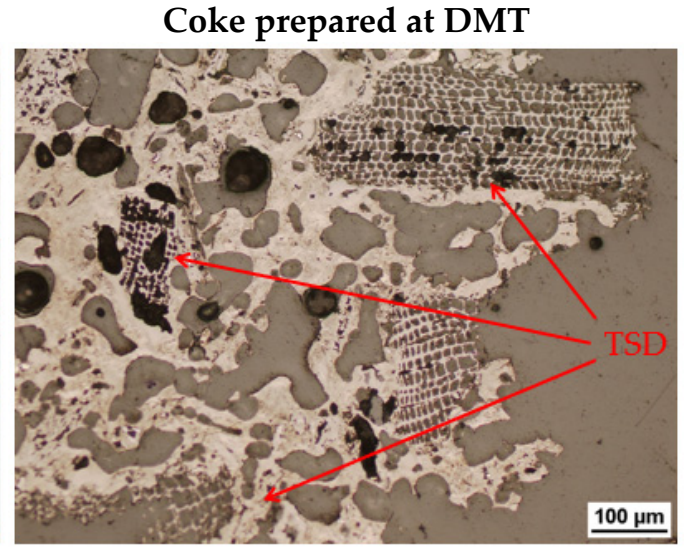

(b)

Figure 8. LOM images showing the microstructure for coke and bio-coke samples for (a) TSD5 and (b) TSD5-DMT.

Analyses using XRF of bio-coke ash showed that there was no significant difference in the ash amount or composition between the produced bio-cokes when 5 or $10 \%$ biocoal was added, as the coals in the basic blend were mainly influencing the average ash composition. However, local variations in ash composition due to the presence of bio-coal ash can still be important. 


\subsubsection{Reactivity of Coke Prepared at Lab and Technical Scale}

Table 9 shows the mass loss of the sample during the reactivity test of coke produced from $\mathrm{BB}$ and bio-coke containing $5 \%$ and 10\% bio-coal. The TGA analysis showed that bio-coke containing $5 \%$ and $10 \%$ bio-coal is more reactive than the BB. HTT5 is an exception, with similar gasification as BB. TFR5 had a higher mass loss than other bio-cokes, with $5 \%$ bio-coal addition. Bio-coke TSD5 and CC5 had quite similar mass losses. HTT10 had a higher mass loss than the other bio-cokes with $10 \%$ bio-coal addition, already occurring at lower temperatures. The gasification of bio-coke containing $5 \%$ bio-coal started at lower temperatures in comparison to $\mathrm{BB}$ and the start of reaction temperature further decreased with $10 \%$ bio-coal in the coking coal blend.

Table 9. Temperature for the start of gasification and accumulated mass loss at different temperatures, as measured in TGA.

\begin{tabular}{|c|c|c|c|c|c|c|}
\hline \multirow{2}{*}{ Types } & \multirow{2}{*}{ Samples } & \multirow{2}{*}{$\begin{array}{c}\text { Start of } \\
\text { Gasification }\left({ }^{\circ} \mathrm{C}\right)\end{array}$} & \multicolumn{4}{|c|}{ Accumulated Mass Loss (\%), Up to Each Temperature } \\
\hline & & & $950^{\circ} \mathrm{C}$ & $1000{ }^{\circ} \mathrm{C}$ & $1050{ }^{\circ} \mathrm{C}$ & $1100{ }^{\circ} \mathrm{C}$ \\
\hline \multirow{3}{*}{$\begin{array}{c}\text { Technical scale coke produced } \\
\text { in retort at DMT }\end{array}$} & $\mathrm{BB}$ & 953 & 0.00 & 0.96 & 4.36 & 11.5 \\
\hline & TSD5 & 943 & 0.86 & 3.13 & 7.69 & 15.9 \\
\hline & HTT5 & 908 & 1.80 & 4.25 & 7.94 & 14.5 \\
\hline \multirow{9}{*}{$\begin{array}{l}\text { Laboratory coke produced } \\
\text { in a Tamman furnace }\end{array}$} & $\mathrm{BB}$ & 964 & 0.23 & 1.63 & 4.94 & 11.2 \\
\hline & TFR5 & 895 & 2.72 & 5.30 & 10.8 & 19.8 \\
\hline & TSD5 & 912 & 1.42 & 3.34 & 7.65 & 15.4 \\
\hline & HTT5 & 905 & 1.49 & 3.30 & 6.36 & 11.9 \\
\hline & CC5 & 919 & 1.50 & 4.31 & 9.65 & 17.9 \\
\hline & TFR10 & 869 & 3.45 & 6.51 & 12.1 & 20.2 \\
\hline & TSD10 & 888 & 2.00 & 4.48 & 9.90 & 18.9 \\
\hline & HTT10 & 884 & 4.49 & 8.68 & 13.2 & 20.7 \\
\hline & CC10 & 875 & 2.44 & 6.07 & 12.0 & 20.9 \\
\hline
\end{tabular}

The quality of coke carbonized at technical scale was analyzed for CRI, CSR, and Micum test, see Table 10. The results showed a higher mass loss for TSD5 compared to HTT5. The same trend was found for the reactivity measured by TGA for lab and technical scale produced coke.

Table 10. Quality of coke prepared at technical scale.

\begin{tabular}{ccccc}
\hline \multirow{2}{*}{ Abbreviations } & \multicolumn{2}{c}{ CRI/CSR Test } & \multicolumn{2}{c}{ Drum Test/Micum } \\
\cline { 2 - 5 } & CRI & CSR & M40 & M10 \\
\hline BB & 28.6 & 57.6 & 80.7 & 7.0 \\
TSD5 & 36.5 & 46.6 & 76.4 & 7.7 \\
HTT5 & 31.8 & 57.8 & 78.5 & 7.8 \\
\hline
\end{tabular}

The drum test results for bio-cokes prepared at DMT showed that the M40 for bio-coke with $5 \%$ bio-coal addition of HTT was quite similar to BB, and this indicates that HTT5 had a high strength. The true density was measured for bio-coke samples carbonized at laboratory and technical scales, and the results were quite equal, 1.89 and $1.82 \mathrm{~g} / \mathrm{cm}^{3}$, respectively.

\section{Discussion}

\subsection{Influence of Bio-Coal Carbonization on the Thermoplastic Properties of Coking Coal}

The maximum dilatation for coking coal blends decreased with $5 \%$ bio-coal addition of torrefied bio-coals (TFR, TSD), whereas it was not significantly changed for CC and HTT. The maximum dilatation decreased further with a 10\% bio-coal addition, especially for TFR and TSD. It has been stated in the literature that the release of $\mathrm{H}_{2}[9,43,44]$ can influence fluidity. However, the release of $\mathrm{H}_{2}$ from bio-coals occurred in a similar temperature range as for coking coals, and can, thus, not explain the impact on fluidity from bio-coal addition. From the results, it is noted that the release of hydrocarbons (for example $\mathrm{CH}_{4}^{+}$detected in 
QMS) from HTT and CC occurred in the plasticity temperature range for the coals, possibly contributing to the better development of plasticity in these blends.

In comparison to HTT or CC, a significantly larger effect on max dilatation was seen when adding TSD and TFR, especially at $10 \%$ addition, which could have been due to the higher $\mathrm{O}_{2}$ content in TFR and TSD, 34\% and 36.5\%, respectively, compared to $15.5 \%$ and $8.3 \%$ for HTT and CC. Mochizuki et al. and Tsubouchi et al. [45,46] found that heteroatoms such as oxygen have a deleterious effect on the plastic properties of coal. From these results, the VM released from bio-coals including a high amount of oxygen is likely to inhibit the thermoplastic properties of the coal, which was discussed in $[13,14]$; however, the use of charcoal with a low oxygen content mainly has effects as an inert material. It was reported that the addition of inert materials to coking coal may cause a reduction in thermoplastic properties, due to the effect from the high surface area of bio-coals acting as adsorbents of the primary decomposition products of coking coal, which binds the plasticizing part of the coal, favoring the inhibition of fluidity development [47].

According to the literature [48], the presence of a higher content of catalytic components, e.g., $\mathrm{K}_{2} \mathrm{O}$ and $\mathrm{CaO}$, in TFR, as mentioned in Table 3, could also have an impact on lowering the dilatation in TFR5 and TFR10. However, as the maximum dilatation is always lower for TSD, the oxygen content seems to be of greater importance. The low $\mathrm{O}_{2}$ content in CC and HTT could be the reason for CC5 and HTT5 having similar maximum dilatations to $\mathrm{BB}$. The $\mathrm{CC} 5$ results agree with $\mathrm{Ng}$ et al. [23], who found that the presence of a $5 \%$ charcoal addition to the blend did not affect the development of a plastic layer of coking coal.

\subsection{Influence of Bio-Coal Addition on Coke Quality}

There are many parameters, i.e., cell structure of bio-coal, amount of reactive carbon originating from bio-coal present in coke, and contribution of catalytic oxides in the ash, that simultaneously affect bio-coke reactivity. Therefore, it is difficult to make a precise conclusion about which parameter is most important.

The TGA results show that the start of the carbon gasification reaction was lowered by a higher bio-coal addition, and this could have been due to an increase in the content of reactive bio-coal carbon that was gasified at a lower temperature in comparison to carbon originating from coking coals. The lowering of the start of gasification temperature for bio-coke, in comparison to a reference coke, was reported in $[18,25,27]$, and according to Suopajärvi et al. [25] it was lowered by $30-50{ }^{\circ} \mathrm{C}$ for bio-coke containing $5 \%$ charcoal. In this study, the temperature was lowered by $45^{\circ} \mathrm{C}$ for a corresponding addition of CC. As expected, in bio-cokes containing bio-coal with a higher content of catalytic components in the ash, the start of gasification occurred at lower temperature and the reactivity was higher, as seen for TFR5 and TFR10, in comparison to TSD5 and TSD10.

The cell structure, i.e., open or closed, may also affect bio-coke reactivity, as it has an impact on the gas diffusion. The compact cell structure of HTT could be the reason for HTT5 having almost the same behavior as BB; but with a higher content of carbon originating from HTT in HTT10, the reactivity is higher than for BB coke, which reflects the complex set of parameters influencing coke reactivity. The CRI and CSR test results for the cokes produced at technical scale show that the difference between HTT5 and BB is minor, and this indicates that it could be possible to maintain the properties of industrial coke with a 5\% HTT addition. The CRI test results for cokes produced at technical scale showed that the CRI values increased in the order BB $<$ HTT5 $<$ TSD5, and vice versa for CSR. The higher CRI for TSD5 could have been due to the difference discussed above; high VM and oxygen content may contribute to the higher porosity of produced bio-coke, which enhances the diffusion of $\mathrm{CO}_{2}$. The low mechanical strength of TSD5 produced at technical scale could have been due to the higher oxygen content in TSD, and this will have a deleterious effect on the plastic properties of coal. The CRI results for the technical scale coke followed the same trend as the reactivity tests conducted in TGA. Hayashizaki et al. [49] reported that the coke strength largely correlated to the dilatation. When the coal dilatation is insufficient, 
the voids between coal particles will not fill up and coal particles will not be tightly bonded together, which decreases the coke strength. This could have also influenced the diffusion of gas within the coke piece.

\section{Conclusions}

This study aimed to understand the impact of different bio-coal types from different origins and pyrolysis degrees, with added amounts of $5 \%$ or $10 \%$ to an industrially used coal blend, on carbonization and quality of bio-coke structure and reactivity. The following conclusions can be drawn:

- Pyrolyzed bio-coals, such as charcoal and high temperature torrefied bio-coal having a devolatilization behavior such as coking coals, did not have a significant effect on the fluidity up to a $5 \%$ addition; while they had a moderate effect on lowering the fluidity at $10 \%$ addition.

- Torrefied bio-coals, such as forest residue and sawdust, with a high content of volatile matter releases hydrocarbons, such as $\mathrm{CH}_{4}^{+}$, at lower temperature than coking coals and have a high $\mathrm{O}_{2}$ content. These properties of bio-coals lead to deleterious effects on the plastic properties of coking coal blends, especially at $10 \%$ addition. However, for bio-coals with a low volatile and oxygen content, the plastic properties, as shown in the optical dilatometer test, are less influenced.

- All addition of bio-coal in cokemaking lowers significantly the starting temperature for gasification, in comparison to reference coke; with differences in the content of catalyzing compounds having a smaller effect.

- Coke produced at laboratory and technical scales from coking coal blends with 5\% addition of high-temperature torrefied pelletized sawdust or 5\% torrefied sawdust show a similar trend in reactivity as measured using thermogravimetric analysis.

- Technical scale produced types of bio-coke showing low reactivity in the thermogravimetric analysis also showed a high quality in standard tests for reactivity, strength after reaction, and mechanical strength, when technical scale produced bio-coke was tested. This indicates that the coking coal blend with a $5 \%$ high temperature torrefied bio-coal could be suitable for industrial use.

Author Contributions: Conceptualization, B.B., L.S.Ö. and M.L.; methodology, A.A.E.-T. and A.R.; formal analysis and investigation, A.A.E.-T.; writing—original draft preparation, A.A.E.-T.; writingreview and editing, L.S.Ö., B.B., M.L. and A.A.E.-T.; supervision, L.S.Ö. and B.B.; project administration, L.S.Ö., B.B. and M.L. All authors have read and agreed to the published version of the manuscript.

Funding: This research was funded by Swedish Research Council for Sustainable Development (FORMAS). The work was carried within the project "Bio-coal as raw material in coke for lower $\mathrm{CO}_{2}$-emission in metal production". Grant number FR-2018/0010.

Data Availability Statement: The data presented in this study are available from the corresponding author, upon reasonable request.

Acknowledgments: Financial support from Swedish Research Council for Sustainable Development (FORMAS) is gratefully acknowledged. In addition, the additional funding provided by Center of Advanced Mining and Metallurgy (CAMM) at Luleå university of technology is acknowledged. For additional support, the following companies are acknowledged; Bioendev AB, Sveaskog AB and SSAB.

Conflicts of Interest: The authors declare no conflict of interest.

\section{References}

1. Geerdes, M.; Chaigneau, R.; Kurunov, I. Modern Blast Furnace Ironmaking: An Introduction; IOS Press: Amsterdam, The Netherlands, 2015; ISBN 1614994994.

2. Suopajärvi, H.; Fabritius, T. Towards more sustainable ironmaking—an analysis of energy wood availability in finland and the economics of charcoal production. Sustainability 2013, 5, 1188-1207. [CrossRef] 
3. WorldSteel Association. Available online: https://www.worldsteel.org/publications/bookshop/product-details $\sim\{$ Steel-scontribution-to-a-low-carbon-future--update-version-coming-shortly- \{\}PRODUCT \{\}contribution-low-carbon-pp \{\} .html (accessed on 18 September 2020).

4. Gupta, R.C. Woodchar as a sustainable reductant for ironmaking in the 21st century. Miner. Process. Extr. Metall. Rev. 2003, 24, 203-231. [CrossRef]

5. Özçimen, D.; Ersoy-Meriçboyu, A. Characterization of biochar and bio-oil samples obtained from carbonization of various biomass materials. Renew. Energy 2010, 35, 1319-1324. [CrossRef]

6. Sundqvist Ökvist, L.; Lundgren, M. Experiences of Bio-Coal Applications in the Blast Furnace Process-Opportunities and Limitations. Minerals 2021, 11,863. [CrossRef]

7. Nomura, S.; Ayukawa, H.; Kitaguchi, H.; Tahara, T.; Matsuzaki, S.; Naito, M.; Koizumi, S.; Ogata, Y.; Nakayama, T.; Abe, T. Improvement in blast furnace reaction efficiency through the use of highly reactive calcium rich coke. ISIJ Int. 2005, 45, 316-324. [CrossRef]

8. Lundgren, M. Development of Coke Properties during the Descent in the Blast Furnace. Ph.D. Thesis, Luleå Tekniska Universitet, Luleå, Sweden, 2013.

9. Fernández, A.M.; Barriocanal, C.; Díez, M.A.; Alvarez, R. Influence of additives of various origins on thermoplastic properties of coal. Fuel 2009, 88, 2365-2372. [CrossRef]

10. Guerrero, A.; Diez, M.A.; Borrego, A.G. Influence of charcoal fines on the thermoplastic properties of coking coals and the optical properties of the semicoke. Int. J. Coal Geol. 2015, 147, 105-114. [CrossRef]

11. Diez, M.A.; Alvarez, R.; Fernández, M. Biomass derived products as modifiers of the rheological properties of coking coals. Fuel 2012, 96, 306-313. [CrossRef]

12. Ueki, Y.; Nunome, Y.; Yoshiie, R.; Naruse, I.; Nishibata, Y.; Aizawa, S. Effect of Woody Biomass Addition on Coke Properties. ISIJ Int. 2014, 54, 2454-2460. [CrossRef]

13. Fraga, M.; Flores, B.; Osório, E.; Vilela, A. Evaluation of the thermoplastic behavior of charcoal, coal tar and coking coal blends. J. Mater. Res. Technol. 2020, 9, 3406-3410. [CrossRef]

14. Solar, J.; Caballero, B.M.; Barriocanal, C.; Lopez-Urionabarrenechea, A.; Acha, E. Impact of the Addition of Pyrolysed Forestry Waste to the Coking Process on the Resulting Green Biocoke. Metals 2021, 11, 613. [CrossRef]

15. Kumar, P.P.; Barman, S.C.; Singh, S.; Ranjan, M. Influence of coal fluidity on coal blend and coke quality. Ironmak. Steelmak. 2008, 35, 416-420. [CrossRef]

16. Coking Coal. Available online: https://www.ispatguru.com/coking-coals/ (accessed on 21 June 2021).

17. Díez, M.A.; Alvarez, R.; Barriocanal, C. Coal for metallurgical coke production: Predictions of coke quality and future requirements for cokemaking. Int. J. Coal Geol. 2002, 50, 389-412. [CrossRef]

18. Ng, K.W.; MacPhee, J.A.; Giroux, L.; Todoschuk, T. Reactivity of bio-coke with $\mathrm{CO}_{2}$. Fuel Process. Technol. 2011, 92, 801-804. [CrossRef]

19. Gupta, A.; Thengane, S.K.; Mahajani, S. $\mathrm{CO}_{2}$ gasification of char from lignocellulosic garden waste: Experimental and kinetic study. Bioresour. Technol. 2018, 263, 180-191. [CrossRef] [PubMed]

20. Grigore, M.; Sakurovs, R.; French, D.; Sahajwalla, V. Influence of mineral matter on coke reactivity with carbon dioxide. ISIJ Int. 2006, 46, 503-512. [CrossRef]

21. Nomura, S.; Kitaguchi, H.; Yamaguchi, K.; Naito, M. The characteristics of catalyst-coated highly reactive coke. ISIJ Int. 2007, 47, 245-253. [CrossRef]

22. Babich, A.; Senk, D.; Gudenau, H.W. Effect of coke reactivity and nut coke on blast furnace operation. Ironmak. Steelmak. 2009, 36, 222-229. [CrossRef]

23. Ng, K.W.; Giroux, L.; MacPhee, T.; Todoschuk, T. Incorporation of charcoal in coking coal blend-A study of the effects on carbonization conditions and coke quality. In Proceedings of the AISTech 2012: Proceedings of the Iron \& Steel Technology Conference, Atlanta, GA, USA, 7-10 May 2012; pp. 225-236.

24. Ng, K.W.; Giroux, L.; MacPhee, T.; Todoschuk, T. Biofuel Ironmaking Strategy from a Canadian Perspective: Short-Term Potential and Long-Term Outlook. In Proceedings of the 1st International Conference on Energy Efficiency and CO2 Reduction in the Steel Industry, Düsseldorf, Germany, 27 June-1 July 2011.

25. Suopajärvi, H.; Dahl, E.; Kemppainen, A.; Gornostayev, S.; Koskela, A.; Fabritius, T. Effect of charcoal and Kraft-lignin addition on coke compression strength and reactivity. Energies 2017, 10, 1850. [CrossRef]

26. MacPhee, J.A.; Gransden, J.F.; Giroux, L.; Price, J.T. Possible $\mathrm{CO}_{2}$ mitigation via addition of charcoal to coking coal blends. Fuel Process. Technol. 2009, 90, 16-20. [CrossRef]

27. Flores, B.D.; Flores, I.V.; Guerrero, A.; Orellana, D.R.; Pohlmann, J.G.; Diez, M.A.; Borrego, A.G.; Osório, E.; Vilela, A.C.F. Effect of charcoal blending with a vitrinite rich coking coal on coke reactivity. Fuel Process. Technol. 2017, 155, 97-105. [CrossRef]

28. Yustanti, E.; Wardhono, E.Y.; Mursito, A.T.; Alhamidi, A. Types and Composition of Biomass in Biocoke Synthesis with the Coal Blending Method. Energies 2021, 14, 6570. [CrossRef]

29. Rejdak, M.; Bigda, R.; Wojtaszek, M. Use of alternative raw materials in coke-making: New insights in the use of lignites for blast furnace coke production. Energies 2020, 13, 2832. [CrossRef]

30. Matsumura, T.; Ichida, M.; Nagasaka, T.; Kato, K. Carbonization Behaviour of Woody Biomass and Resulting Metallurgical Coke Properties. ISIJ Int. 2008, 48, 572-577. [CrossRef] 
31. Florenonti-Madiedo, L.; Casal, D.; Díaz-Faes, E.; Barriocanal, C. Effect of sawdust addition on coking pressure produced by two low vol bituminous coals. J. Anal. Appl. Pyrolysis 2017, 127, 369-376. [CrossRef]

32. Montiano, M.G.; Díaz-Faes, E.; Barriocanal, C.; Alvarez, R. Influence of biomass on metallurgical coke quality. Fuel 2014, 116, 175-182. [CrossRef]

33. Montiano, M.G.; Díaz-Faes, E.; Barriocanal, C. Effect of briquette composition and size on the quality of the resulting coke. Fuel Process. Technol. 2016, 148, 155-162. [CrossRef]

34. ALS Scandinavia AB. Available online: https://www.alsglobal.se/en (accessed on 15 September 2020).

35. SSAB. Available online: https://www.ssab.se/ssab-koncern/om-ssab/produktionsorter-i-sverige/lulea (accessed on 15 September 2020).

36. BioEndev AB. Available online: http:/ / www.bioendev.se/ (accessed on 15 September 2020).

37. Sveaskog AB. Available online: https://www.sveaskog.se (accessed on 15 September 2020).

38. Vindelkol AB. Available online: https://vindelkol.se/ (accessed on 15 September 2020).

39. DMT. Available online: https:/ / www.dmt-group.com/ (accessed on 21 September 2020).

40. Gajic, D. Influences on Bulk Density and Its Effect on Coke Quality and Internal Gas Pressure. In Proceedings of the AISTech-Iron and Steel Technology Conference Proceedings, Pittsburgh, PA, USA, 6-9 May 2013; pp. 307-319.

41. Gajic, D.; Kaiser, M. New findings from the DMT small-scale coking test retort regarding coke quality and coke oven wall safety. In Proceedings of the AISTech 2012: Proceedings of the Iron \& Steel Technology Conference, Atlanta, GA, USA, 7-10 May 2012; pp. 237-246.

42. El-Tawil, A. Bio-Coal as an Alternative Reducing Agent in the Blast Furnace. Ph.D. Thesis, Luleå University of Technology, Luleå, Sweden, 2020.

43. Nomura, M.; Kidena, K.; Hiro, M.; Murata, S. Mechanistic study on the plastic phenomena of coal. Energy Fuels 2000, 14, 904-909. [CrossRef]

44. Grint, A.; Mehani, S.; Trewhella, M.; Crook, M.J. Role and composition of the mobile phase in coal. Fuel 1985, 64, 1355-1361. [CrossRef]

45. Mochizuki, Y.; Naganuma, R.; Tsubouchi, N. Influence of inherently present oxygen-functional groups on coal fluidity and coke strength. Energy Fuels 2018, 32, 1657-1664. [CrossRef]

46. Tsubouchi, N.; Mochizuki, Y.; Naganuma, R.; Kamiya, K.; Nishio, M.; Ono, Y.; Uebo, K. Influence of inherent oxygen species on the fluidity of coal during carbonization. Energy Fuels 2016, 30, 2095-2101. [CrossRef]

47. Loison, R.; Foch, P.; Boyer, A. Coke: Quality and Production; Elsevier: Amsterdam, The Netherlands, 2014 ; ISBN 1483165272.

48. Khan, M.R.; Jenkins, R.G. Influence of added calcium compounds on swelling, plastic, and pyrolysis behaviour of coal devolatilized at elevated pressures. Fuel 1986, 65, 1203-1208. [CrossRef]

49. Hayashizaki, H.; Hayashi, Y.; Kubota, Y.; Uebo, K.; Nomura, S. Development of Coal Blending Technology for Improvement of Coke Quality; Technical Report; Nippon Steel: Tokyo, Japan, 2020. 